Psychopharmacologia (Berl.) 17, 100-104 (1970)

\title{
Experimental Variables in the Effects of Postsession Injections of Strychnine Sulphate on a Classically Conditioned Response
}

\author{
Charles F. Levinthat and James D. Papsdorf \\ Department of Psychology, University of Michigan, Ann Arbor, \\ Michigan 48104 \\ Received April 17, 1969 \\ Final Version: December 8, 1969
}

\begin{abstract}
Summary. Postsession strychnine injections have been shown to retard acquisition rates of the classically conditioned nictitating membrane response (CCNMR) of rabbits trained at a CS-US interval of $1000 \mathrm{msec}$. The particular interval value employed in CCNMR aequisition was found to be important in the magnitude of the postsession strychnine effect. Strychnine $S s$ trained at a CS-US interval $=1250$ msec (nonoptimal) were significantly depressed in acquisition rates relative to saline controls, while strychnine $S \mathrm{~s}$ trained at a CS-US interval $=250 \mathrm{msec}$ (optimal) were not. Interpretations are based upon the presumed effects of CNS excitants on memory consolidation and possible neurological correlates of the CS-US interval parameter.
\end{abstract}

Key-Words: Classical Conditioning - Strychnine - Consolidation - Nictitating Membrane.

Cholewiak, Hammond, Seigler, and Papsdorf (1968) have recently reported a depression in the acquisition rates of the classically conditioned nictitating membrane response of the rabbit as a result of immediate postsession i.p. injections $(0.3 \mathrm{mg} / \mathrm{kg})$ of strychnine sulphate. Although the Cholewiak et al. study is the only one involving postsession injections in a classical conditioning paradigm, numerous other studies have investigated strychnine effects in instrumental approach and avoidance tasks as well as in more cognitive problems. Postsession strychnine facilitation has been observed in complex maze learning (McGaugh, Thomson, Westbrook and Hudspeth, 1962), in a visual discrimination problem (Krivanek and Hunt, 1967) in a delayed alternation response task (Petrinovitch, Bradford and McGaugh, 1965), in shuttle box avoidance (Bovet, McGaugh and Oliverio, 1966) and in an oddity discrimination problem (Hudspeth, 1964). Performance facilitation has generally been interpreted in terms of an enhancement of consolidative processes underlying memory formation (McGaugh, 1966).

The evidence accumulated by McGaugh and others of a postsession strychnine facilitation makes the Cholewiak et al. observation appear 
anomalous. However, the growing evidence concerning the influences of experimental parameters upon postsession effects makes difficult direct comparison of strychnine studies. A relevant factor, for example, appears to be the postsession environment, under which the drug takes effect. In the Cholewiak et al. study, the rabbits were returned immediately after injection to the home cage. Unpublished observations from the Michigan laboratory show no depressive effects following postsession injections of strychnine when rabbits were maintained in the experimental enclosure for 30 minutes following drug injection. Calhoun (1966) has varied the postsession environment following postsession injection of strychnine, finding that when there were high levels of stimulation strychnine depressed performance in a spatial discrimination task, but when there were low levels of stimulation strychnine facilitated performance. In addition, Irwin (1967) has observed that postsession injections of metrazol could facilitate retention of a passive avoidance response only if following injections $S$ s were maintained up to the time of testing in a plastic eage rather than in the home cage.

In an effort to generalize the postsession strychnine effect of the Cholewiak et al. study, experimental parameters were altered in a later study to include a shorter CS-US interval (300 msec instead of $1000 \mathrm{msec}$ ), fewer trials per session ( 5 per session instead of 15 per session), and a higher dosage of strychnine $(0.5 \mathrm{mg} / \mathrm{kg}$ instead of $0.3 \mathrm{mg} / \mathrm{kg})$, Despite the higher drug dosage and shorter conditioning session, postsession strychnine depression was not observed. As the CS-US interval parameter has been shown to be a powerful determinant of conditioning rates (Schneiderman and Gormezano, 1964) with CS-US intervals of 250 to $400 \mathrm{msec}$ providing most rapid conditioning, the less optimal (1000 msec) interval of the Cholewiak et al. investigation might have been critical to their finding. The following experiment was designed to test this possibility.

\section{Method}

Subjects. Thirty-one male albino New Zealand rabbits $80-100$ days old were obtained through the facilities of the Animal Care Unit of the University of Michigan and maintained on ad-lib food and water.

Procedure. Apparatus and procedure are described in detail by Gormezano (1966). Forty-eight hours prior to the first experimental session, a small nylon loop was sutured into $S$ 's right nictitating membrane. On the following day, each $S$ was placed in a Plexiglas restraining box for a 10-minute habituation period. During this period, as in the experimental sessions, tailor hooks, which served to retract the eyelids and deliver the shock US, were fastened by an adjustable Velcro strap to the inferior and superior lids of the right eye. Movements of the nictitating membrane were monitored by a small photoelectric transducer 


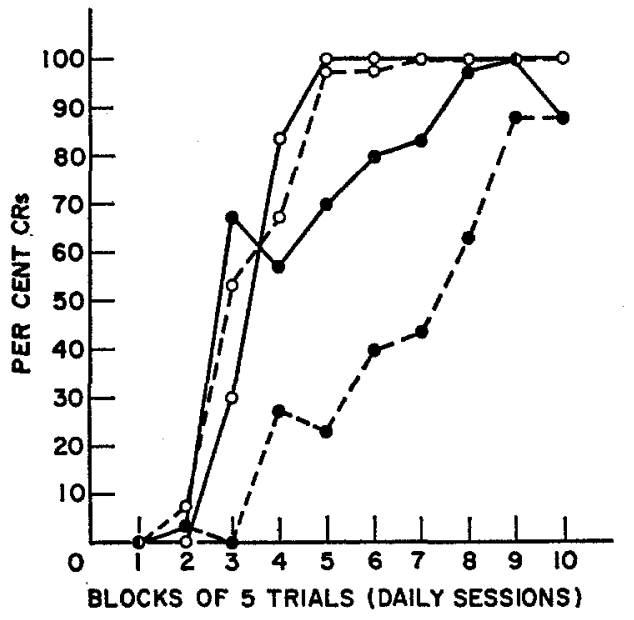

Fig. 1. Percentage of CRs of $S$ s receiving immediate postsession injections of strychnine sulphate or saline at either of two CS-US intervals (in msec). oSaline-250; 0- - 0 Strych-250;

Saline-1250; $-\cdots$ Strych-1250 mounted on the $S$ 's snout by means of a muzzle-like assembly and mechanically coupled to the loop in the membrane. Signals from the transducer were amplified and graphically recorded by a Beckman 'Type R Dynograph.

On each of 10 subsequent days, is received 5 CS-US pairings at a variable intertrial interval averaging $1 \mathrm{~min}$. The CS, a $1000 \mathrm{~Hz}$ tone at $93 \mathrm{db}$. SPL, was presented against a continuous white noise background of $70 \mathrm{db}$. SPL for either $350 \mathrm{msec}$ or 1350 msec. The US was a 3 ma. $60 \mathrm{~Hz}$ shock delivered across the eyelids and overlapping the $100 \mathrm{msec}$ of CS presentation.

$S$ s were randomly assigned to four groups in a $2 \times 2$ design with CS-US intervals of $250 \mathrm{msec}$ (optimal) and $1250 \mathrm{msec}$ (nonoptimal) orthogonal to $0.5 \mathrm{mg} / \mathrm{kg}$ i.p. injections of a $1.0 \mathrm{mg} / \mathrm{co}$ solution of strychnine sulphate or a comparable injection of physiological saline. Injections were administered one to two minutes following each conditioning session. $S$ s were returned to home cages immediately after the injections.

\section{Results}

Percentage of CRs across blocks of 5 trials is plotted in Fig. 1.

Over sessions $3-9$, at CS-US interval $=250 \mathrm{msec}$, performance of strychnine $S$ s and saline $S$ s were essentially equivalent. However, at CS-US interval $=1250 \mathrm{msec}$ the CR level of strychnine $S$ s was from $12 \%$ to $67 \%$ below that of saline $S \mathrm{~s}$. Analysis of variance yielded a significant CS.US interval effect $(F=9.76, d f=1 / 20, p<0.01)$ CS-US interval $\times$ Trials interaction $(F=4.33, d f=9 / 180, p<0.01)$, and CSUS interval $\times$ Drug $\times$ Trials interaction $(F=2.49, d f=9 / 180, p$ $<0.05$ ), the latter indicating that the magnitude of postsession strychnine depression was determined by the CS-US interval employed.

The mean percentages of CRs summed over sessions 2-10 for Saline-250 and Strychnine-250 Ss were $79.3 \%$ and $80.0 \%$ respectively. Equivalent measures for Saline-1250 and Strychnine-1250 Ss were $71.5 \%$ and $41.5 \%$ respectively. 
A conservative a posteriori analysis of variance (Winer, 1962) regarding the conditional effect of the drug at CS-US interval $=1250 \mathrm{msec}$ was statistically significant $(F=4.10, d f=2 / 20, p<0.05)$.

\section{Discussion}

In agreement with the finding of Cholewiak et al. (1968), postsession injections of strychinne sulphate produced a significant depression in the rate of conditioning of Ss trained at a nonoptimal CS-US interval. Three possible hypotheses accounting for this depression may be considered: 1. A drug-induced enhancement of central sensitivity to peripheral stimulation (Smolin and Samko, 1968) might make enviromental conditions of the home cage disruptive for memory consolidation, 2 . the environmental conditions of the home cage might evoke an emotional response incompatible with that elicited by the experimental enclosure which, when in the presence of the CNS excitant, might compete with the taskrelated consolidative processes, or 3. there might exist a generalization of inhibition from excessive non-reinforeed blinking in the strychnine $S$ s.

The generalization of inhibition hypothesis is initially appealing due to its success in accounting for the ISI-strychnine interaction. Hartman and Grant (1962) have shown data suggesting longer recruitment times for inhibitory processes than for excitatory ones. Longer CS-US intervals would provide the needed time for inhibition recruitment to occur. However, the prediction would have to be made that $S$ s returned to the experimental enclosure for a period of time following injection would show a greater strychnine depression than those returned to home cages after injection. Unpublished data from the Michigan laboratory as indicated earlior show the opposite result. A somewhat similar difficulty resides in the hypothesis of consolidation of competing response tendencies. It would be difficult to identify the cues in the experimental enclosure that would be able to elicit the competing response tendencis acquired in the home cage.

Thus, the most promising hypothesis for the depression effect appears to involve increased sensitization to peripheral stimulation. In order to account for the parametric interaction, this hypothesis must assume that the optimal and nonoptimal interval groups differ in the neural configuration coding the CS-US contingency, so as to involve a differential vulnerability to drug-produced interfering neural events. As a proposed mechanism for simple classical conditioning, John (1967) has suggested that the reverberatory overlap of coherent neural activity in a US dominant focus as a consequence of afferent input from a CS dominant focus underlies the neural basis of associative development. If a long CS-US interval activated a more complex common mode of activity 
relative to a short interval, with a greater number of synapses where neuronal interaction could occur, the long CS-US interval system could be considered more vulnerable to interfering activity.

To the extent that CS-US interval influences the characteristios of the neuronal coding of the CS-US event, the classical conditioning paradigm, where the parameter can be brought under experimental control, should be helpful in more detailed analyses of the processes underlying memory consolidation.

\title{
References
}

Bovet, D., MoGaugh, J. L., Oliverio, A.: Effects of posttrials administration of drugs on avoidance learning of mice. Life Sci. 5, 1309-1319 (1966).

Calhoun, W. H.: Effect of level of external stimulation in learning and interaction of this effect with strychnine treatment in mice. Psychol. Rep. 18, 715-722 (1966).

Cholewiak, R. W., Hammond, R., Seigler, I. C., Papsdorf, J. D.: The effects of strychnine sulphate on the classically conditioned nictitating membrane response of the rabbit. J. comp. physiol. Psychol. 66, 77-81 (1968).

Gormezano, I.: Classical conditioning. In: J. B. Sidowski (Ed.): Experimental instrumentation in psychology. New York: McGraw-Hill 1966.

Hartman, T. F., Grant, D. A.: Differential eyelid conditioning as a function of the CS-US interval. J. exp. Psychol. 64, 131-136 (1962).

Hudspeth, W. J.: Strychnine: Its facilitatory effect on the solution of a simple oddity problem by the rat. Sciences 145, 1331-1333 (1964).

Irwin, S.: Response to Pearl, J., and McKean, D. B. Pentylenetetrazol: Failure to improve memory in mice. Science 157, 22 (1967).

John, E. R.: Mechanisms of memory. New York: Academic Press 1967.

Krivanek, J., Hunt, E. : Unpublished observations (1967). Cited by J. L. McGaugh. Paper read at Sixth Annual Meeting of the American College of Neuropsychopharmacology: San Juan, Puerto Rico, December 1967.

MoGaugh, J. L.: Time-dependence processes in memory storage. Science 153, $1351-1358$ (1966).

- Thomson, C.W., Westbrook, W.H., Hudspeth,W.J.: A further study of learning facilitation with strychnine sulphate. Psychopharmacologia (Berl.) 3, $352-360$ (1962).

Petrinovitch, L. F., Bradford, D., MeGaugh, J. L.: Drug facilitation of memory in rats. Psychon. Sci. 2, 191-192 (1965).

Schneiderman, N., Gormezano, I.: Conditioning of the nictitating membrane response of rabbit as a function of CS-US interval. J. comp. physiol. Psychol. 57, $188-195$ (1964).

Smolin, L. N., Samko, N. N.: Action of strychnine sulphate on the specific somatosensory projection pathway. Int. J. Neuropharm. 7, 155-160 (1968).

Winer, B. J.: Statistical principles in experimental design. New York: McGraw-Hill 1962.

\author{
Charles F. Levinthal \\ Psychological Laboratories \\ 3439 Mason Hall \\ University of Michigan \\ Ann Arbor, Michigan 48104, U.S.A.
}

